\title{
REGISTRATION OF A WILL DEED AT PROPERTY AND HERITAGE AGENCY (BALAI HARTA PENINGGALAN / BHP)
}

\author{
Ken Safira $^{1}$, Zainal Asikin ${ }^{2}$, Aris Munandar ${ }^{3}$ \\ ${ }^{1}$ Graduate Program Student in Notary, Faculty of Law, Mataram University, Indonesia \\ ${ }^{2,3}$ Lecturer of Faculty of Law, Mataram University, Indonesia \\ E-Mail: kensafira95@gmail.com
}

\begin{abstract}
This study aims to understand the reasons for registering a will deed to the Property and Heritage Agency (Balai Harta Peninggalan / BHP) and find out the reasons why a will must be registered to the Property and Heritage Agency and the sanctions received by the Notary as well as the form of responsibility of the Notary if he does not register a will to the Property and Heritage Agency. This research is focused on normative legal research, which essentially examines laws that are conceptualized as norms or rules that apply in society and become a reference for everyone's behavior. The research approaches used include the statutory approach and the conceptual approach. The conclusion in this study is that the purpose of registering a will to the Property and Heritage Agency is a form of announcement so that later when the testator dies, the heirs and testament recipients know that there is a will that has been made by the testator during his lifetime. For a Notary who does not carry out his obligations to register and report a will to the Property and Heritage Agency may be subject to sanctions in the form of a written warning, temporary dismissal, honorable discharge or dishonorable discharge. For those who feel they have suffered a loss, they have the right to demand reimbursement of costs or compensation to a Notary through the courts.
\end{abstract}

Keywords: Will Deed, Property and Heritage Agency, Heirs

DOI: $10.7176 / \mathrm{JLPG} / 114-06$

Publication date:October $31^{\text {st }} 2021$

\section{INTRODUCTION}

The treasures that have been collected during life will certainly not be taken to death. In general, the property of someone who has died will fall to his family and closest people or better known as heirs. According to KlaassenEggens, inheritance law is the law that regulates the transfer of property and the occurrence of legal relationships as a result of a person's death. ${ }^{1}$

This is in line with the provisions in Article 830 Burgerlijk Wetboek (hereinafter referred to as BW) which states that inheritance only takes place because of death where this provision is further regulated in the provisions of Article $874 \mathrm{BW}$ which confirms that all assets left behind by a person who dies, belong to all his heirs according to the law, only with respect to that by a will no legal decision has been taken. In BW there are two ways to get inheritance, namely:

1. As an heir according to the provisions of the law (ab intestate);

2. Because someone is appointed in a will (testamentair). ${ }^{2}$

The person who has the property wishes that when he dies his property can be used according to the needs of the heirs. For this reason, the law allows the owner of the property to give his property according to his own wishes where this deviates from the provisions of the inheritance law, this is reasonable because in principle a property owner is free to treat his property as he wishes. ${ }^{3}$ However, in reality there are not a few conflicts in terms of the distribution of abandoned property or what is also called inheritance by the owner of the object.

In this regard, the owner of the object or in this case also called the heir, makes a will relating to his inheritance. This will is made while the testator is still alive and will only take effect after the testator dies. What is meant by a will or testament itself according to Article $875 \mathrm{BW}$ is a deed containing a statement of a person about what he wants will happen after he dies, and by which it can be revoked again.

Wills are distinguished based on their content and form. Judging from its contents, wills are divided into two, namely erfstelling or wills for the appointment of heirs and legaat or wills containing grants (will grants). As for the form, wills are divided into wills that must be written by themselves (Olographis Testament), general wills (Openbaar Testament), and secret wills or closed testaments (Geheim). ${ }^{4}$

\footnotetext{
${ }^{1}$ R. Soetojo Prawirohamidjojo, Codified Inheritance Law, (Surabaya: Airlangga University Press, 2000), p. 1.

${ }^{2}$ Zainuddin Ali, Implementation of Inheritance Law in Indonesia, (Jakarta: Sinar Graphic, 2010), p. 82.

${ }^{3}$ Oemarsalim, The Basics of Inheritance Law in Indonesia, (Jakarta: Rineka Cipta, 2012), p. 82.

${ }^{4}$ Maman Suparman, Civil Inheritance Law, (Jakarta: Sinar Graphic, 2015), p. 107.
} 
Each type and form of the will above can be made either in an authentic deed before a Notary or a private deed. The notary has the duty and obligation to keep and send the list of wills he has made to the Property and Heritage Agency (hereinafter referred to as BHP) and the Will Register Center.

In order to realize the efficiency of the registration system, on March 28, 2014, the Ministry of Law and Human Rights of the Republic of Indonesia issued an online will registration system by a Notary. Furthermore, Regulation of the Minister of Law and Human Rights Number 60 of 2016 concerning Procedures for Reporting Wills and Requests for Issuance of Electronic Will Certificates has been issued (hereinafter referred to as Permenkumham No. 60 of 2016) as the basis for online will reporting. In Article 16 paragraph (1) letter j of Law Number 2 of 2014 concerning Amendments to Law Number 30 of 2004 concerning the Position of a Notary (hereinafter referred to as UUJN) states that in carrying out his position, Notaries are obligated to send a list of deeds as referred to in letter i or a list of nil wills to the ministry that administers government affairs in the legal field within 5 (five) days in the first week of each following month. However, the new Law on Notary Positions does not mention the sanctions for each delay, both delays in registering wills to the Ministry of Law and Human Rights of the Republic of Indonesia and delays in sending repertorium records.

Article 943 BW stipulates that each Notary who keeps wills among the original documents, in whatever form, must, after the testator dies, notify all interested parties. Based on these provisions, it can be seen that the Notary has an important function in making a will from the beginning to the end so that the will has binding legal force.

Carelessness and negligence of a Notary who does not register a will by itself has a wide legal impact. This will not only have an impact on the will, but also for the Notary, the Center for the List of Wills and third parties with an interest in the will. Please note, based on the Law on Notary Positions (UUJN) Notaries are required to report whether or not there is a will deed every month. Even if in the current month the Notary does not make a will, the notary must still report zero will. Likewise, in the case of making a will, the reporting and registration of a will must be carried out by a Notary not later than the 5 th of each month.

What is certain is that in UUJN any violation of the provisions of Article 16 paragraph 12 of Law Number 2 of 2014, can be used as a legal basis for parties suffering losses to claim reimbursement of costs, compensation and interest from a Notary. Article 16 paragraph 10 has clearly stipulated that a violation of Article 16 paragraph 9 does not cause the will deed to have the power of proof under the hand. However, what is clear is that for every violation of UUJN by a Notary, the Notary who violates the UUJN can be subject to administrative sanctions in accordance with the provisions of the UUJN.

In Article 84 of the UUJN it is stated that a Notary can be subject to sanctions if he does not carry out the obligations in Article 16 paragraph 1 letters h, i, and $\mathrm{j}$. Parties who suffer losses can claim reimbursement of costs, compensation, and interest from a Notary. Whereas in Article 85 it is stated that a Notary may be subject to sanctions in the form of verbal warning, written warning, temporary dismissal, honorable discharge, or dishonorable discharge.

In Article 10 paragraph 1 of Permenkumham Number 60 of 2016 it is stated that a Notary who does not report the Register of Deeds or the Zero List to the Center for the List of Wills or is late in submitting it, all legal consequences arising in connection with this shall be the responsibility of the Notary concerned. Meanwhile, sanctions are imposed in accordance with statutory regulations.

Based on the description above, this study aims to understand the reasons for registering a will to the Property and Heritage Agency (Balai Harta Peninggalan) and find out the sanctions received by the Notary and the form of responsibility of the Notary if he does not register the will. Therefore, the author compiled a thesis with the title "REGISTRATION OF A WILL DEED AT PROPERTY AND HERITAGE AGENCY (BALAI HARTA PENINGGALAN / BHP)".

\section{LITERATURE REVIEW}

\section{Legal Liability Theory}

Purbacaraka argues that, "legal responsibility originates or is born from the use of facilities in the application of each person's ability to exercise their rights and/or carry out their obligations". ${ }^{1}$

There are two terms that refer to responsibility in the legal dictionary, namely liability and responsibility. Liability is a broad legal term that designates almost any character of risk or responsibility, which is certain, which depends on or which may include all the characteristics of actual or potential rights and obligations such as losses, threats, crimes, costs or conditions that create the duty to carry out the law. Responsibility means things that can be accounted for by an obligation, and includes decisions, skills, abilities and skills including the obligation to be responsible for the laws that are implemented. ${ }^{2}$

\footnotetext{
${ }^{1}$ Purbacaraka, Regarding Legal Rules, (Bandung: Citra Aditya, 2010), p.37

${ }^{2}$ Ridwan HR, State Administrative Law, (Jakarta: Raja Grafindo Persada, 2006), p. 335-337.
} 


\section{Legal Protection Theory}

The beginning of the emergence of the theory of legal protection comes from the theory of natural law or the flow of natural law. This flow was pioneered by Plato, Aristotle (Plato's student), and Zeno (founder of the Stoic school). According to the flow of natural law, it states that the law comes from God, which is universal and eternal, and that law and morals cannot be separated. The adherents of this school view that law and morals are a reflection and regulation internally and externally of human life which is realized through law and morals. ${ }^{1}$

According to Thomas Aquinas, "natural law is a provision of reason that comes from God which aims for good and is made by people who take care of society to be disseminated. There are differences in the views of philosophers about the existence of natural law, but in other aspects it also raises a number of hopes that the search for the absolute is a human yearning for the nature of justice. Natural law as a rule that is universal, eternal, and applies absolutely, it turns out that even in modern life it will still exist as evidenced by the increasing number of people talking about human rights issues."2

Theoretically the form of legal protection is divided into two forms, namely: ${ }^{3}$

1) Preventive protection; and

2) Repressive protection.

Preventive legal protection aims to prevent disputes and is very meaningful for government actions based on freedom of action. While repressive legal protection aims to resolve in the event of a dispute.

\section{Legal Certainty Theory}

Certainty is a matter (state) that is certain, provisions or stipulations. The law must essentially be certain and fair. It must be a code of conduct and fairness because the code of conduct must support an order that is considered reasonable. Only because it is fair and carried out with certainty the law can carry out its functions. Legal certainty is a question that can only be answered normatively, not sociologically. ${ }^{4}$

According to Kelsen, law is a system of norms. Norms are statements that emphasize aspects of 'should' or das sollen, by including some rules about what must be done. Norms are the product of deliberative human action. Laws containing general rules serve as guidelines for individuals to behave in society, both in relation to fellow individuals and in relation to society. These rules become limitations for society in burdening or taking action against individuals. The existence of these rules and the implementation of these rules create legal certainty. ${ }^{5}$

Normative legal certainty is when a regulation is made and promulgated with certainty because it regulates clearly and logically. Clear in the sense of not causing doubt (multi-interpretation) and logical. It is clear in the sense that it becomes a norm system with other norms so that it does not clash or cause norm conflicts. Legal certainty refers to the application of a clear, permanent, consistent and consequent law whose implementation cannot be influenced by subjective circumstances. Certainty and justice are not merely moral demands, but factually characterize the law. An uncertain and unjust law is not just a bad law. ${ }^{6}$

If it is related to the purpose of registering the will itself, then the registration aims to guarantee the rights of both the giver and the beneficiary of the will. Where the purpose of the registration is so that the will has legal force and cannot be changed at any time like an underhand will.

\section{Notary Concept}

According to Article 1 paragraph 1 of Law Number 2 of 2014 concerning Amendments to Law Number 30 of 2004 concerning the Position of a Notary, the definition of a Notary is a public official who is authorized to make an authentic deed and has other authorities as referred to in this Law or based on other laws.

Notary principles that characterize Latin notaries are public officials appointed by the state, authorized to make authentic deeds who carry out their positions independently and impartially and keep the contents of the deed and information obtained confidential. The function of a notary is not limited to making an authentic deed but with philosophical, sociological and juridical grounds and reasons, the notary can detect the possibility of

\footnotetext{
${ }^{1}$ Marwan Mas, Introduction to Legal Studies, Issue I, Ghalia Indonesia, Bogor, 2014, p. 116.

${ }^{2}$ Ibid, p. 133.

${ }^{3} \mathrm{H}$. Salim HS and Erlies Septiana Nurbani, Application of Legal Theory in Thesis and Dissertation Research, Issue III, Rajawali Pers, Jakarta, 2014, p. 264.

${ }^{4}$ Dominikus Rato, Seeking Legal Philosophy: Understanding and Understanding Law, Laksbang Pressindo, Yogyakarta, 2010, p. 59

${ }^{5}$ Peter Mahmud Marzuki, Introduction to Law, Kencana, Jakarta, 2008, p. 158.

${ }^{6}$ Cst Kansil, Christine, ST Kansil, Engelien R, Paladeng and Godlieb N Mamahit, Dictionary of Legal Terms, Jakarta, 2009, p. 385 .
} 
bad faith and unwanted consequences as well as protect parties with weak socio-economic and juridical positions thereby protecting third parties with good intentions.

\section{Concept of Will}

Article 875 of the Civil Code states that a will or testament is a deed containing a person's statement about what he wants to happen after he dies, which can be revoked by him.

The statement was made by the author as a testator to nominate several people to take care of his property if the testator dies..Although the letter must be made in written form or deed,Civil law does not specify whether it must be made in the form of a private deed or an authentic deed, so both are allowed.

The requirements for making a will include:

1) The legal testator is someone who has grown up, (i.e. at least 18 years old).

2) The testator must have common sense. Common sense in question is spiritual health that does not disturb the soul of the testator. Apart from spiritual health, The testator must also not be under pressure or coercion when writing a will.

3) The ownership of the object of the will must legally belong to the testator and be stated in detail. The mention of the object of the will in detail and clearly must be adjusted to the documents of ownership of the object of the will.For example, for assets in the form of land, Certificate of Ownership must be in the name of the testator.

4) A will should be signed by all interested parties. Interested parties include the testator, Notary and witnesses. The notary's signature is affixed to the letter or supporting deeds of the will so that the authenticity of the letter and its legal force is sufficient.

\section{Concept of Willing Deed Registration}

In some circumstances, inheritance can lead to conflict. Inheritance can even be a source of slander and division. If one of the heirs feels that there is an unfair distribution of inheritance, it will result in a dispute with the other heirs. To prevent conflicts that could cause divisions in the family, a will was made.

According to J. Satrio, formally a testament is a deed that meets the requirements of the law (Article 930 BW and so on). Whereas materially the testament is a statement of will, which only has consequences/valid after the testament maker dies, which statement at the time the maker was still alive can be withdrawn unilaterally. ${ }^{1}$

An authentic deed has the power of outward proof (strength that proves that the presence of the authentic deed is in accordance with the applicable laws), formal (which is stated in the authentic deed is true as long as it cannot be proven that it is not true) and material (provides legal certainty that the information provided by the deed is true). ${ }^{2}$

With the Notary not registering and reporting the will to the Center for the Will Register, the strength of the deed, especially outwardly and materially, can be doubted, even though the external proof itself is the signature of the official, namely the Notary, is the authenticity of the deed itself and for material evidence, namely as long as whatever is contained in the document. The deed has absolute material proof power for the parties.

\section{Property and Heritage Agency Concept}

Regarding the task of the Property and Heritage Agency as an absentee treasure manager, there is a regulation in particular in the Regulation of the Minister of Law and Human Rights Number M.02-HT.05.10 of 2005 concerning Applications for Permits for the Sale of Assets whose Owners are Declared Absent and Unmanaged Heritage Assets Under the Management and Supervision of Property and Heritage Agency as amended by Regulation of the Minister of Law and Human Rights Number 27 of 2013 concerning Amendments to Ministerial Regulations Law and Human Rights Number M.02-HT.05.10 of 2005 concerning Applications for Permits for the Sale of Assets whose Owners are Declared Absent and Unmanaged Heritage Assets Under the Management and Supervision of the Property and Heritage Agency (BHP).

The definition of BHP can be seen in Article 1 point 1 of Permenkumham 27/2013 as follows: Property and Heritage Agency is a technical implementing unit at the Regional Office of the Ministry of Law and Human Rights of the Republic of Indonesia under the Division of Legal Services and Human Rights which is technically directly responsible to the Director General of General Legal Administration,has the task of representing and

${ }^{1}$ J. Satrio, Inheritance Law, (Bandung: Alumni, 1992), p. 181.

${ }^{2}$ Cita Astungkoro Sukmawirawan, "The Power of Proving the Legalization and Waarmeking of Underhanded Deeds by Notaries", Scientific Article of Student Research Results, Faculty of Law, University of Jember, 2014, p. 6. 
managing the interests of people who because of the law or court decisions/decision cannot carry out their own interests based on statutory regulations.

\section{RESEARCH METHOD}

This research is focused on normative legal research, which essentially examines laws that are conceptualized as norms or rules that apply in society and become a reference for everyone's behavior. The research approaches used include the statutory approach and the conceptual approach.

In this research, sources of legal materials are used to support the data obtained, namely: Primary legal materials, secondary legal materials, and tertiary legal materials. The technique of collecting legal materials that support and relate to the presentation of this research is document study (library study). Document study is a tool for collecting legal materials through written legal materials using a content analyzer. ${ }^{1}$

Because the norms studied are vague norms, the analysis tool is legal interpretation. The interpretation used in this research is systematic interpretation. Systematic interpretation is interpreting the law by connecting one article with another article in a piece of legislation or with other laws. ${ }^{2}$ Furthermore, the data is recorded systematically and consistently, so that the data obtained in this study can be written with the management critically, logically, and systematically, so that later it can reveal a norm of a problems.

\section{DISCUSSION}

\section{A. The Importance of Registering a Will at The Property and Heritage Agency}

One of the powers of a Notary is to make a will deed. Notaries make a list of deeds related to wills according to the order in which the deeds are made every month. This authority is important to guarantee the protection of the interests of the heirs and heirs, which at any time can be traced to the truth of a will that has been made before a Notary. All wills made before a Notary must be notified to the Central Section of the List of Wills, both open wills (openbaar testament), written wills (olographis testament), or closed or secret wills. If the will is not notified, the will will not be binding on the parties involved in the will.

If in the month related to a Notary's office a will is not made, it will not cause problems if the Notary does not send a report regarding the making of a will. It will be a problem if it turns out that a will has been made, but the list of deeds is not sent by the Notary. In Chapter XI regarding the provision of sanctions in Article 84 of Law Number 30 of 2004 concerning the Position of a Notary, it is said that if a Notary commits an act of violating the provisions referred to in Article 16 paragraph 1 letter i, it will result in a degradation of the strength of proof of the Notary deed, ${ }^{3}$ a deed only has the power of proof as an underhand deed or a deed becomes null and void so that it can be a reason for the party suffering losses to demand reimbursement of costs, compensation, and interest to a notary. However, based on Article 1 number 42 of the UUJN, the provisions of Chapter XI were deleted and the UUJN no longer contained provisions regarding the legal consequences of a will whose deed was not reported by a Notary. Article 16 paragraph 11 and paragraph 12 of the UUJN only emphasizes the sanctions that can be imposed on Notaries who violate the provisions of Article 16 paragraph 1 letter $\mathrm{j}$ which in the provisions of Article 91A of the UUJN it is stated that the provisions regarding the procedures for imposing sanctions (as referred to in Article 16 paragraph 11) regulated in a Ministerial Regulation.

So it can be concluded that a will that is not registered at the Property and Heritage Agency, the legal position of the deed remains as an authentic deed where this online registration is only a form of administrative order and can be used as a reason for the parties concerned to try to cancel the will, because of obligations regarding the registration has been regulated in the legislation. So that if this provision is violated, the legal consequence is that the will can be used as the basis for a lawsuit by the heirs.

\section{Procedure for Registration of Wills at the Property and Heritage Agency}

The flow of the will registration service before it is done online is as follows: ${ }^{4}$

1. The applicant submits the application by bringing a copy of the will.

2. The receptionist records the request and submits the request to the Chairperson of the Property and Heritage Agency.

\footnotetext{
${ }^{1}$ Peter Mahmud Marzuki, Legal Research, (Jakarta: Kencana Prenada Media Group, 2011), p. 21.

${ }^{2}$ Yudha Bhakti Ardiwisastra, Interpretation and Legal Construction, (Bandung: PT. Alumni, 2012), p. 11.

${ }^{3}$ Eko Hariyanti, et al., "Cancellation of the Deed of Will Grant Made before a Notary and its Legal Consequences", Journal of the Repertorium Edition 3, ISSN: 2355-2646, (January-June 2015): 184, http://jurnal. Hukum.uns.ac.id/index.php/repertorium/article/view/654/612 accessed on November 11, 2020.

4 Surabaya Heritage Center, "The Flow of Wills Registration Service", https://bhpsurabaya.com/index.php/jasapublik/pengurusan-wasiat\#alur-pelayan accessed on November 10, 2020.
} 
3. The chairman dispenses the request.

4. The secretary validates the requirements of the application.

5. The Head of the Administration sub-section records and distributes applications to Legal Technical Members according to the disposition of the Chairman.

6. The Legal Technical Member will be assigned to the Section Head.

7. The Section Head drafts/types the list of wills according to the number and date of the will.

8. The Legal Technical Member corrects and initials the letter.

9. Draft to Secretary for final correction.

10. Draft to the Chair and signed.

Based on the author's interview with Notary Baiq Mariana Setiarni, SH. M.KN, one of the Notaries in the city of Mataram, the registration of the will to the Property and Heritage Agency is done through the official website of the Directorate General of AHU: www.ahu.go.idby selecting the "Will" menu. The contents of the will reporting format are as follows: ${ }^{1}$

1. The identity of the testator, which includes: full name (including first name or alias if any), place and date of birth, occupation, address, and identity card number.

2. Number, date and month and year of making the will.

3. Type of will.

4. Repertorium number of wills.

If there is no will that needs to be registered in the current month, the Notary will choose the "Nil" statement in the Nil List report.

\section{The Role of Notaries in Making Wills}

According to Law Number 2 of 2014 concerning Amendments to Law Number 30 of 2004 concerning the Position of a Notary, the definition of a Notary is a public official who is authorized to make authentic deeds and has other authorities as referred to in this Law or based on other laws. .

Notaries have a very important role in Indonesia to serve the community in terms of making authentic deeds as evidence or as legal/absolute requirements for certain legal actions. Notary principles that characterize notaries are public officials appointed by the state, authorized to make authentic deeds who carry out their positions independently and impartially and keep the contents of the deed and information obtained secret. Notaries carry out their positions and maintain attitudes, behavior in accordance with laws and regulations and the Notary Code of Ethics.

Based on article 16 paragraph (1) UUJN, in carrying out his office, a Notary is obliged to:

1. act honestly, thoroughly, independently, impartially, and safeguard the interests of the parties involved in legal actions;

2. make a deed in the form of minutes of deed and save it as part of the Notary protocol;

3. issue a grosse deed, a copy of a deed, or a deed quote based on the minutes of the deed;

4. provide services in accordance with the provisions of this law, unless there is a reason to refuse it;

5. keep everything about the deed he made and all information obtained for the making of the deed in accordance with the oath or promise of office, unless the law provides otherwise;

6. bind the deed he made in 1 (one) month into a book that makes no more than 50 (fifty) deeds, and if the number of deeds cannot be contained in 1 (one) book, the deed can be bound into more than 1 (one) book, and record the number of minutes of deed, month, and year of manufacture on the cover of each book;

7. make a list of the deed of protest against non-payment or non-receipt of securities;

8. make a list of deeds relating to wills according to the order in which the deed was made every month;

9. send a list of deeds as referred to in letter $\mathrm{h}$ or a list of nil with regard to wills to the Center for the List of Wills (DPW) of the Department whose duties and responsibilities are in the notary field within 5 (five) days in the first week of each following month;

10. record in the repertoire the date of sending the list of wills at the end of each month;

11. has a stamp or seal containing the symbol of the Republic of Indonesia and in the space surrounding it the name, position, and place of domicile of the person concerned are written;

\footnotetext{
${ }^{1}$ Interview with Notary Baiq Mariana Setiarni, SH. M.KN on December 21, 2020 online.
} 
12. read the deed before the appearer in the presence of at least 2 (two) witnesses and signed at the same time by the appearer, witnesses, and a notary;

13. accept the internship of a prospective Notary.

In a written testament (olographis testament), if a living person makes a will and submits it to a notary, the notary must first save the will.

Every Notary who keeps a written will and a closed or secret will is obliged to submit the said will to the local Property and Heritage Agency after the testator dies. In addition, the Notary is also obliged to report or notify a person's will on the first 5 (five) Sundays of each month.

\section{Property and Heritage Agency}

Definition of Property and Heritage Agency can be seen in Article 1 point 1 Permenkumham 27/2013 as follows: "Property and Heritage Agency (Balai Harta Peninggalan) is a technical implementing unit at the Regional Office of the Ministry of Law and Human Rights of the Republic of Indonesia under the Division of Legal Services and Human Rights which is technically directly responsible to the Director General of General Legal Administration, has the task of representing and managing the interests of people who by law or court decisions/stipulations cannot carry out their own interests based on the laws and regulations."

The implementation of the main tasks and functions of the BHP is guided by Articles 2 and 3 of the Decree of the Minister of Justice Number M.01.PR.07.01-80 of 1980 concerning the Organization and Work Procedure of the Property and Heritage Agency ("Kepmen Kehakiman M.01/1980"), as following:

a. Article 2 Decree of the Minister of Justice M.01/1980

The task of the Property and Heritage Agency is to represent and manage the interests of people who because of the law or a judge's decision cannot carry out their own interests based on the applicable laws and regulations.

b. Article 3 Decree of the Minister of Justice M.01/1980

To carry out the tasks referred to in article 2, the Property and Heritage Agency has the following functions:

1) Carry out the settlement of guardianship, custodial, absenteeism and inheritance problems that are not authorized and other problems regulated in the legislation.

2) Carry out bookkeeping and registration of wills in accordance with statutory regulations.

3) Carry out the resolution of bankruptcy problems in accordance with the laws and regulations.

In more detail from the provisions contained in Articles 2 and 3 of the Minister of Justice M.01/1980 above, the main tasks and functions of the Heritage Center include: ${ }^{1}$

1) As Supervisory Guardian and Temporary Guardian (Article 366 and 359 last paragraph of the Civil Code);

2) Supporting children in the womb and supervising supervisors in custody (Articles 348 and 449 of the Civil Code);

3) Opening of closed/confidential wills and registration of general wills (Articles 937 and 942 of the Civil Code);

4) The management of the inheritance is not managed/has no proxy (Article 1126 to Article 1130 of the Civil Code in conjunction with Article 64 to Article 69 of Staatsblad 1872/166);

5) Representing and managing the assets of people who are declared absent/afwezig (Article 463 of the Civil Code in conjunction with Article 61 of Staatsblad 1872/166);

6) Curator in bankruptcy (Article 70 paragraph (1) letter aLaw Number 37 of 2004 concerning Bankruptcy and Suspension of Debt Payment Obligations);

7) Making a certificate of inheritance rights for Indonesian Citizens (WNI) of Foreign Eastern descent (paragraph 1 Article 14 of the Voor de Gouvernement Landmeters Instruction in Stbl. 1916 Number 517 jo. Regulation of the State Minister of Agrarian Affairs/Head of the National Land Agency Number 3 of 1997 concerning Provisions for the Implementation of Government Regulation Number 24 of 1997 concerning Land Registration);

8) The holder of the death security and old-age security funds in the event that the workforce does not have heirs and wills (Article 22 paragraph (3a), Article 26 paragraph (5) Government Regulation

\footnotetext{
${ }^{1}$ Abi Jam'an Kurnia, SH, https://www. Hukumonline.com/klinik/detail/review/task-dan-function-balai-harta-peninggalan, accessed on January 20, 2021.
} 
Number 53 of 2012 concerning the Eighth Amendment to Government Regulation Number 14 of 1993 concerning the Implementation of the Workers' Social Security Programjo.Regulation of the Minister of Law and Human Rights Number 13 of 2013 concerning Receipt and Management of Workers' Social Security Program Funds at the Heritage Center); and

9) Receipt and management of proceeds of cash transfers based on Article 37 paragraph (3)Law Number 3 of 2011 concerning Fund Transfers.

\section{The Role of the Property and Heritage Agency in the Distribution of Inheritance}

If there is an inheritance left by someone who has died, but there is no one who becomes his heir, then the said property is called an unmanaged inheritance. Under these circumstances, without waiting for an order from the judge, the Property and Heritage Agency (in Islamic inheritance law is called Baitul Mal) is obliged to take care of the inheritance. The management work must be reported to the local state attorney. If there is a dispute about whether an inheritance is considered managed or not, then this determination will be decided by the judge. ${ }^{1}$

The obligations that must be carried out by the Property and Heritage Agency in its task of managing unmanaged inheritance include the following: ${ }^{2}$

1. It is obligatory to make details or an inventory of the condition of the inheritance, which is preceded by the sealing of the goods.

2. The obligation to clean up the inheritance in the sense of collecting the heirs' receivables and paying all the debts of the heirs, if requested by the authorities, the Property and Heritage Agency is also obliged to provide accountability.

3. Obligation to call the heirs who may still exist through newspapers or other official calls.

\section{Requirements for Registering a Will Deed to the Property and Heritage Agency}

The following are the requirements that must be prepared to register a will at the Property and Heritage Agency: ${ }^{3}$

1. Application letter,

2. Death Certificate/Death Certificate from Hospital,

3. All heirs must be present at the BHP and the Notary keeping the will,

4. Wills,

5. Identity of the Parties,

6. Certificate of Will from the Directorate General of General Legal Administration (AHU) of the Ministry of Law and Human Rights of the Republic of Indonesia.

\section{Position and Functions of Wills}

Basically, a notary deed is a document that has strong legal force. The deed has 2 (two) important functions, namely the deed as a formal function which means that a legal act will be more complete if a deed is made. The function of evidence is the deed as a means of proof where the deed is made by the parties bound in an agreement intended for proof at a later date. ${ }^{4}$ The function of the will is basically as a means to determine who the heirs are entitled to an object of inheritance belonging to the testator. The purpose of making the inheritance deed itself is so that there is no seizure of the object of inheritance between the heirs.

\section{B. The Notary's Responsibilities to the Wills Made in His Presence}

Notary accountability can be categorized into 3 (three) types. The various forms of responsibilities of the Notary include the following:

\section{Notary Administrative Responsibilities}

The authority that must be possessed by a Notary is only allowed to carry out his position in a legal area that has been determined and stipulated in the UUJN and within that jurisdiction a Notary has the authority to perform all

${ }^{1}$ Zainuddin Ali, Implementation of Inheritance Law in Indonesia, (Jakarta: Sinar Graphic, 2010), p. 97.

${ }^{2}$ Op city., p. 97-98.

${ }^{3}$ DKI Jakarta Heritage Center, "Requirements for Will Registration", https://bhpjakarta.kemenkumham.go.id/index.php/jasapublik/pengurusan-wasiat\#percepatan accessed on November 10, 2020.

${ }^{4}$ Sudikno Mertokusumo, Knowing the Law is an Introduction (Revised Edition), Cahaya Atma, Yogyakarta, 2013, pp. 121122. 
forms of actions in carrying out his profession. In administrative law, Notaries are given authority based on UUJN. If the provisions are not heeded, it will have legal consequences, the deed made by the Notary can become a private deed and the deed can be canceled or null and void by law.

The authority possessed by a Notary includes 4 (four) things, namely, as follows: ${ }^{1}$

a. The notary must be authorized as far as the deed is made.

b. The notary must be authorized as long as it concerns the people, for whose interest the deed was made.

c. The notary must be authorized as long as it concerns the place where the deed was made.

$\mathrm{d}$. The notary must be authorized as long as the time of making the deed is concerned.

Administrative responsibilities of a Notary can be seen from Law Number 2 of 2014 concerning Amendments to Law Number 30 of 2004 concerning the Position of a Notary. Notary administrative responsibilities will arise when the Notary's obligations are not carried out properly. Notary administrative accountability is carried out if there is an act that can be punished for violating the elements that are expressly regulated in the UUJN.

Notaries who have violated the law may be subject to administrative sanctions. Broadly speaking, administrative sanctions include: ${ }^{2}$

a. Government coercion (bestuursdwang)

As a real action or feitelijke handeling from the authorities in order to end a situation that is prohibited by a rule of administrative law or if they are still doing what citizens should have abandoned because it is against the law.

b.Withdrawal of favorable decisions/stipulations (permits, payments, subsidies)

Sanctions are used by revoking or withdrawing a favorable decision or provision by issuing new provisions. This sanction is applied in the event of a violation of the rules or conditions attached to the written determination that has been given, as well as a violation of the law relating to the permit held by the violator. A favorable revocation or withdrawal is a situational sanction, namely a sanction that is issued not with the intention of being a reaction to an act that is despicable from a moral point of view, but is intended to end conditions that are objectively unjustifiable.

c. Imposition of administrative fines

The sanctions for imposing administrative fines are aimed at those who violate certain laws and regulations and the violators are subject to a certain amount of money based on the relevant laws and regulations.

d.Imposition of forced money by the government (dwangsom)

The sanction of imposition of forced money by the government is intended to add to a definite punishment in addition to the fines that have been explicitly stated in the relevant legislation.

Regarding administrative sanctions for Notaries who make mistakes, it can be seen in the provisions of Article 85 of Law Number 2 of 2014 concerning Amendments to Law Number 30 of 2004 concerning Notary Positions, it is stated that Notaries can be subject to sanctions in the form of:

a.verbal reprimand;

b.Written reprimand;

c. Temporary suspension;

d.Dismissal with honor; or

e. Disrespectful dismissal.

The sanctions mentioned above are sanctions that can be imposed by the Notary Supervisory Board and are carried out in stages according to the form of violation committed by the Notary. Article 67 paragraph (1) of the UUJN stipulates that the Minister who supervises the Notary is carried out and in carrying out the supervision the Minister forms a Supervisory Council (Article 67) paragraph (2) of the UUJN. Article 67 paragraph (3) of the UUJN determines that the Supervisory Council consists of 9 (nine) people, consisting of 3 (three) government elements, 3 (three) notary organizations and 3 (three) experts/academics.

\section{Notary Civil Liability}

The Civil Code regulates legal liability in a civil manner. This responsibility arises from the law (as an unlawful act) as well as from agreements, as well as with the Civil Code in other countries in the legal system that arises as a result of unlawful acts according to the Civil Code, are: ${ }^{3}$

a. Responsibility with elements of error (intentional and negligence, as contained in Article 1365 of the

Civil Code

\footnotetext{
${ }^{1}$ M. Luthfan Hadi Darus, Notary Law and Notary Position Responsibilities, Issue I, UII Press, Yogyakarta, 2017, p. 55. 198-1999.

${ }^{2}$ Sjaifurrachman, Aspects of Notary Accountability in Making Deeds, Issue I, Mandar Maju, Surabaya, 2011, p.

${ }^{3}$ M. Luthfan Hadi Darus, Op. Cit., p. 64.
} 
b. Responsibility with the element of error, especially the element of negligence as contained in Article 1366 of the Civil Code;

c. Absolute liability (without fault) in a very limited sense is found in Article 1367 of the Civil Code.

Civil liability is closely related to acts that violate the law and compensate for losses due to actions that have been carried out by someone. If the Notary commits an act that violates the law and causes a loss for the action taken, the party who feels aggrieved by the Notary's action can file a civil lawsuit to the District Court or Religious Court.

UUJN expressly states the civil responsibilities of a Notary as regulated in Article 84 of the UUJN which states that an act of violation committed by a Notary that results in a deed under the hand or a deed being null and void can be a reason for the party suffering losses to claim reimbursement of costs, compensation and interest to the Notary.

In Article 84 of the UUJN it is determined that there are 2 (two) types of civil sanctions, if a Notary commits a violation of certain articles and also sanctions of the same type are spread in other articles, namely a Notary Deed which has the power of proof as an underhand deed. and the Notary Deed becomes null and void.

Article 1365 of the Civil Code regulates unlawful acts which read that every unlawful act that causes harm to another person, obliges the person who because of his fault published the loss, to compensate for the loss. The elements contained in Article 1365 of the Civil Code concerning Unlawful Acts are the existence of an act, the act is against the law, an error on the part of the perpetrator, there is a loss for the victim and there is a clause relationship between the act and the loss. Article 1366 of the Civil Code states that everyone is responsible, not only for losses caused by actions, but also for losses caused by negligence or carelessness. Likewise in Article 1367 it is stated,

Unlawful acts can occur due to intentional and negligence. Therefore, a Notary as a profession whose duties and authorities are given by law must use the precautionary principle to avoid errors or omissions that may occur. Unlawful acts committed by a Notary in the category of acts that violate civil law, deserve and deserve to be accounted for by a Notary. If the unlawful act committed by the Notary causes harm to the parties, the Notary must also compensate for the losses and costs incurred as a result of the unlawful act.

3. Notary Criminal Liability

Determining the existence of a criminal act is based on the principle of legality, namely the principle that there is no prohibited act and is threatened with a criminal if it is not determined in advance in the legislation, while determining the existence of criminal liability is based on the principle of error. Another term for this principle of error is the principle of not being punished if there are no mistakes. The error qualification relates to several aspects, including: ${ }^{1}$

a. The certainty of the day, date, month, year and time of the face;

b.Parties (who) appear before a Notary;

c. Attendant's signature;

d. The copy of the deed does not match the minutes of the deed;

e. A copy of the deed exists without the minutes of the deed being made;

f. The minutes of the deed are not signed in full, but the minutes deed is issued.

The UUJN and the Notary Code of Ethics stipulate that when a Notary in carrying out his duties and positions is proven to have committed a Notary violation, he can be subject to sanctions in the form of civil sanctions and administrative sanctions but does not regulate criminal sanctions against Notaries. So that if it is proven to have committed a crime against a Notary, it can be subject to criminal sanctions contained in the Criminal Code.

According to Habib Adjie, the conviction of the Notary can be carried out with the following limitations: ${ }^{2}$

a. There are legal actions from the Notary on the outward, formal and material aspects of the deed which are intentionally full of awareness and conviction and it is planned that the deed to be made before the Notary or by the Notary together (agree) with the appearers is used as the basis for committing a crime.

b. There is a legal action from a Notary in making a deed before or by a Notary which when measured based on the UUJN is not according to UUJN.

c. The Notary's actions are also inappropriate according to the agency authorized to assess the actions of a Notary, in this case Notary Supervisory Board.

${ }^{1}$ Habib Adjie, Indonesian Notary Law, Refika Aditama, Bandung, 2014, p. 25.

${ }^{2}$ Sjaifurrachman, Op. Cit, p. 208-209. 
Criminal liability cannot be separated from the provision of sanctions that will be imposed as a result of the act. In general, there are several criminal acts that are often committed by Notaries in carrying out their positions, including the following: ${ }^{1}$

a. Criminal acts regarding forgery of letters as contained in Article 263 paragraphs (1), (2) and Article 264

concerning forgery of authentic documents and Article 266 of the Criminal Code concerning ordering forgeries to be used as if they were not fake;

b. The crime of embezzlement as contained in Article 372 of the Criminal Code;

c. The crime of fraud as contained in Article 378 of the Criminal Code.

A Notary is obliged to carry out his duties with full responsibility, where the responsibilities include: ${ }^{2}$

1. Moral Responsibility

In carrying out his duties, a Notary may not conflict with public order or decency. Regulations related to public order are directly related to the public interest, both regulations that are a mixture of civil law and public law. While the rules regarding good decency are those that have a relationship with the morals that apply in the social life of the community. In this case, as long as it involves actions that are considered contrary to public order and morality, the Notary may refuse to provide assistance.

In carrying out his duties, a Notary may not distinguish between people whose economic conditions are weak and those whose economic conditions are strong. This is in accordance with Article 37 of the UUJN which reads: "Notaries are obliged to provide legal services in the notarial field for free to people who cannot afford".

\section{Ethical Responsibilities}

A Notary in carrying out his position must have sufficient legal skills based on a sense of responsibility for the nobility, dignity of his position and ethics. For Notaries, these requirements are not only required by law but also based on the trust given to them by law, namely Law Number 2 of 2014 concerning Amendments to Law Number 30 of 2004 concerning Notary Positions, both from the nature of the position. The notary himself as well as the nobility and dignity of the position requires the existence of responsibility and personality as well as high legal ethics. In this case, a Notary is responsible for the professional code of ethics which is supervised by the Supervisory Council.

3. Legal Responsibilities

Legal responsibilities include 2 (two) aspects, namely:

a. Formal aspect

According to Article 39 paragraph (2) UUJN states that: "The appearer must be known by a Notary or introduced to him by 2 (two) identifying witnesses who are at least 18 years old or have been married and are capable of carrying out legal actions, or introduced by 2 (two) other facets."

The appearers are those who come before the Notary to make the deed, not those who are represented in the deed, whether represented orally or in writing or in position or position.

b. Material aspect

The provisions in Article 58 paragraph (1) of the UUJN state that: "Notaries make a list of deeds, a list of legalized private letters, a list of registered private letters, and a list of other documents required by this law".

It is an obligation for a Notary if he knows of someone who has died, or information about the absence of the testator, to notify the interested parties quickly about the existence of a will that is stored in the Notary protocol.

\section{Legal Consequences of Unregistered Wills to the Property and Heritage Agency}

One of the powers of a Notary is to make a will. Notaries make a list of deeds related to wills according to the order in which the deeds are made every month. This authority is important to guarantee the protection of the interests of the heirs and heirs, which at any time can be traced to the truth of a will that has been made before a notary. All wills made before a Notary must be notified to the Central Section of the List of Wills, whether open wills, written wills, or closed or secret wills.

If the will is not notified, then the will will not be binding. So it can be concluded that if the Notary does not report the deed, the consequences will be quite fatal for the beneficiary because the person concerned cannot get his rights.

${ }^{1}$ M. Luthfan Hadi Darus, Op. Cit., p. 81.

${ }^{2}$ Mireille Titisari Miarti Prastuti, Thesis: "Roles and Responsibilities of Notaries for the Testament Act Made before Him" (Semarang: Diponegoro University, 2006), p. 66-68. 


\section{Sanctions Given to Notaries Who Do Not Register a Will to the Property and Heritage Agency}

Legal certainty as one of the objectives of the law can be said as part of efforts to realize justice. The real form of legal certainty is the implementation or enforcement of the law against an action regardless of who does it. With legal certainty, everyone can predict what will be experienced if they take certain legal actions. Certainty is needed to realize the principle of equality before the law without discrimination. ${ }^{1}$

Certainty is an inseparable feature of law, especially for written legal norms. Law without the value of certainty will lose its meaning because it can no longer be used as a behavioral guide for everyone. Certainty itself is referred to as one of the goals of law. ${ }^{2}$

According to Sudikno Mertokusumo, legal certainty is a guarantee that the law is carried out in a good way. ${ }^{3}$ That those who are entitled according to law can get their rights and that decisions can be implemented. Legal certainty is the implementation of the law according to its sound so that the community can ensure that the law is implemented.

Accountability cannot be separated from the sanctions that will be imposed on the Notary. Sanctions given to Notaries are in the form of administrative sanctions. In Article 85 of the UUJN it is determined that there are 5 (five) types of administrative sanctions, namely verbal warnings, written warnings, temporary dismissals, respectful dismissals, and dishonorable dismissals. In Article 85 of the UUJN, placing an oral warning in the first order of sanctioning is a warning to a Notary from the Supervisory Council which, if not fulfilled, will be followed up with a written warning. If this kind of sanction is not complied with by the Notary concerned, the next sanction may be imposed in stages. ${ }^{4}$

Placement of sanctions in the form of verbal warnings and written warnings as a prelude to imposing sanctions which subsequently do not include administrative sanctions. In administrative sanctions in the form of government coercion, before being imposed sanctions must be preceded by an oral warning and a written warning, this is included as an aspect of the actual coercive procedure. ${ }^{5}$ In the implementation of verbal warnings and written warnings, those who are given verbal and written warnings have the right to defend themselves in an administrative effort in the form of administrative objections or appeals. Thus, the formulation of sanctions in the form of verbal warnings and written warnings is not appropriate to be included as a sanction, but is only the initial stage to impose real coercive sanctions if it is proven that other sanctions can be imposed.

Sanctions against a Notary in the form of temporary dismissal from his position are the next stage after the imposition of an oral warning and a written warning. The position of sanctions in the form of temporary dismissal from the position of a Notary or suspension is a period of waiting for the implementation of government coercive sanctions. ${ }^{6}$ The purpose of giving a temporary dismissal sanction for a Notary is so that the Notary does not carry out his duties for a while before the sanction in the form of a respectful dismissal or dishonorable discharge is imposed on the Notary. The provision of this temporary dismissal sanction can end in the form of reinstatement to the Notary to carry out his duties again or be followed up with a sanction of honorable dismissal or dishonorable discharge.

The temporary dismissal of a Notary from his position means that the Notary concerned has temporarily lost his authority and the Notary concerned is unable to carry out his/her duties. During this temporary suspension, the Notary awaits the results of the examination conducted by the Supervisory Council.

When explored more deeply, apart from the administrative sanctions stated in Article 16 paragraph (11) of the UUJN, it turns out that there are other sanctions for Notaries. The provisions regarding the sanctions are regulated in Article 16 paragraph (12) which states that in addition to being subject to sanctions as referred to in paragraph (11), violations of the provisions of Article 16 paragraph (1) letter $\mathrm{j}$ can be a reason for parties who suffer losses to demand reimbursement of costs, compensation, and interest to the Notary. In this context, why the term liability is used is because the sanctions mentioned above emphasize the existence of losses for a party so that it would be more appropriate to use the term liability.

\footnotetext{
${ }^{1}$ Bodenheimer in Satjipto Rahardjo, Legal Studies, Bandung: PT. Citra Aditya Bakti, 2006, p. 277.

2 A. Anugrahni. 2013. Understanding (In) Legal Certainty.https://ngobrolin Hukum.wordpress.com/2013/02/05/memahamikepastian-dalam-law/ accessed on 18 November 2020.

${ }^{3}$ Gres News. 2017. Know the Principle of Legal Assurance. Know the Principle of Legal Certainty (gresnews.com) accessed on 18 November 2020

${ }^{4}$ Dr. Habib Adjie, SH. M. Hum., Civil and Administrative Sanctions against Notaries as Public Officials, Bandung: PT. Refika Aditama, 2017, p. 114.

${ }^{5}$ Philipus M. Hadjon, et al., Introduction to Indonesian Administrative Law (Introduction to The Indonesian Administrative Law), Yogyakarta: Gajah Mada University Press, 2002, p. 234.

${ }^{6} \mathrm{Op}$. cit
} 
The form of liability adopted by Article $1365 \mathrm{BW}$ is liability based fault. This can be seen in the provisions of the article which requires the perpetrator to be wrong to arrive at a decision whether someone's actions are unlawful acts. There are four criteria for unlawful acts, the four criteria are: ${ }^{1}$

1. Contrary to the legal obligations of the perpetrator;

2. Violating the subjective rights of others;

3. Violating the rules of ethics;

4. Contrary to the principles of propriety, thoroughness and caution that a person should have in association with fellow citizens or against other people's property.

To find out whether the Notary in the context of this case actually committed an unlawful act or not, the elements of Article 1365 BW which regulates unlawful acts will first be described. Article 1365 BW stipulates that every unlawful act that causes harm to another person, requires the person who caused the loss to be wrong, to compensate for the loss. The elements of Article $1365 \mathrm{BW}$ include:

1. The existence of an action;

2. There is an error;

3. There is a loss;

4. There is a causal relationship or causality.

By paying attention to the description of the elements of Article $1365 \mathrm{BW}$ regarding unlawful acts in which there are elements of actions, mistakes, losses and causal relationships, the actions of a Notary who do not register a will by itself have fulfilled these elements so that it can be said that what has been done by a Notary is an act that violates the law.

The word protection according to the General Indonesian Dictionary means a place of refuge or an act to protect, for example providing protection to weak people. ${ }^{2}$ Meanwhile, according to Sudikno Mertokusumo, the definition of law is a collection of rules or methods that have general and normative content, but because they apply in general and normative, general because they apply to everyone and normative because they determine what should be done, what should not be done or should be done. carried out and determine how to implement compliance with the rules. ${ }^{3}$ So, legal protection is an act to protect legal subjects with applicable regulations and enforced with a sanction.

\section{CONCLUSION}

Based on the findings and discussion of the research, it can be concluded that the registration of a will is very important, because a will is a legal document in the form of an authentic deed containing legal actions, which contains orders or obligations to do something or prohibits taking certain actions; contains the revocation of the previous testament; or contains the appointment of a guardian or executor of a will.

The purpose of registering a will at the Property and Heritage Agency is to make it easier to obtain information whether during his life the testator made a will or not. Registration of this will is necessary to ensure legal certainty of the contents of the will. A will deed made by a Notary but is not registered is still valid as an authentic deed and is not null and void because it still fulfills the elements of an authentic deed and does not also apply as a private deed. The loss of the authentic nature of the will if there is a judge's decision based on the plaintiff can prove that the deed is not true and prove his assessment or statement according to the applicable legal rules through a court process.

Notaries who do not carry out their obligations to register and report wills to the Property and Heritage Agency may be subject to administrative sanctions in the form of a written warning, temporary dismissal, honorable discharge or dishonorable discharge. For those who feel they have suffered a loss, they have the right to sue or sue in a civil manner in the form of reimbursement of costs or compensation to a Notary through the courts.

\section{Suggestion}

Based on the results of the research, the writer expects the Notary to carry out his duties well, especially in making and registering a will at the Property and Heritage Agency. A notary must not be negligent in carrying out his duties to register a will, because there are rights and obligations of the testator and the beneficiary that must be protected. Registering a will is also one of the obligations of a Notary in carrying out his professional duties. Where if the will is not registered, it will cause the Notary to be subject to sanctions and this can tarnish the good name of the Notary profession.

${ }^{1}$ Sjaifurrachman, Op. Cit, p. 179.

${ }^{2}$ WJS Poerwadarminta, General Indonesian Dictionary, Cet. IX, (Jakarta: Balai Pustaka, 1986), p. 600.

${ }^{3}$ Sudikno Mertokusumo, Knowing the Law (An Introduction), (Yogyakarta: Liberty, 1991), p. 38. 
The author suggests that a notification be made to the public in the form of an announcement that someone has left a will during his lifetime. The public referred to in this case is for example the village head or the community around the place of residence of the testator. Announcements can be made through newspapers or announcements directly at the village hall without disclosing the contents of the will. The goal is to know that the testator has made a will in his lifetime.

The author hopes that in the future there will be special regulations governing wills, in particular the sanctions and responsibilities of the Notary specifically if the Notary does not register the will with the Property and Heritage Agency.

\section{REFFERENCES}

Book

Adjie, Habib. 2017. Sanksi Perdata dan Administratif terhadap Notaris sebagai Pejabat Publik, PT. Refika Aditama : Bandung.

Ali, Zainuddin. 2010. Pelaksanaan Hukum Waris di Indonesia, Sinar Grafika : Jakarta.

Darus, M. Luthfan Hadi. 2017. Hukum Notariat dan Tanggungjawab Jabatan Notaris, UII Press : Yogyakarta.

Ardiwisastra, Yudha Bhakti. 2012. Penafsiran dan Konstruksi Hukum, PT.Alumni : Bandung.

H.R., Ridwan. 2006. Hukum Administrasi Negara, Raja Grafindo Persada : Jakarta.

H.S., H. Salim \& Erlies Septiana Nurbani. 2014. Penerapan Teori Hukum Pada Penelitian Tesis dan Disertasi, Cetakan III, Rajawali Pers : Jakarta.

Hadjon, Philipus M., dkk., 2002. Pengantar Hukum Administrasi Indonesia (Introduction to The Indonesia Administratif Law), Gajah Mada University Press : Yogyakarta.

Kansil, Cst, dkk. 2009. Kamus Istilah Hukum, Jakarta.

Marzuki, Peter Mahmud. 2008. Pengantar Ilmu Hukum, Kencana : Jakarta. 2011. Penelitian Hukum, Kencana Prenada Media Group : Jakarta.

Mas, Marwan. 2014. Pengantar Ilmu Hukum, Cetakan I, Ghalia Indonesia : Bogor.

Mertokusumo, Sudikno. 1991. Mengenal Hukum (Suatu Pengantar), Liberty : Yogyakarta. 2013. Mengenal Hukum Suatu Pengantar (Edisi Revisi), Cahaya Atma : Yogyakarta.

Oemarsalim. 2012. Dasar-Dasar Hukum Waris di Indonesia, Rineka Cipta : Jakarta.

Poerwadarminta, W.J.S. 1986. Kamus Umum Bahasa Indonesia, Balai Pustaka : Jakarta.

Prawirohamidjojo, R. Soetojo. 2000. Hukum Waris Kodifikasi, Airlangga University Press : Surabaya.

Purbacaraka. 2010. Perihal Kaedah Hukum, Citra Aditya : Bandung.

Rahardjo, Satjipto. 2006. Ilmu Hukum, PT. Citra Aditya Bakti : Bandung.

Rato, Dominikus. 2010. Filsafat Hukum Mencari: Memahami dan Memahami Hukum, Laksbang Pressindo : Yogyakarta.

Satrio, J. 1992. Hukum Waris, Bandung : Alumni.

Sjaifurrachman. 2011. Aspek Pertanggungjawaban Notaris dalam Pembuatan Akta, Mandar Maju : Bandung. Suparman, Maman. 2015. Hukum Waris Perdata, Sinar Grafika : Jakarta.

\section{Thesis and Journal}

Prastuti, Mireille Titisari Miarti. 2006. Peran dan Tanggungjawab Notaris Atas Akta Wasiat (Testament Acte) yang Dibuat di Hadapannya. Tesis. Semarang: Universitas Diponegoro.

Sukmawirawan, Cita Astungkoro. 2014. Kekuatan Pembuktian Legalisasi dan Waarmeking Akta di Bawah Tangan oleh Notaris. Artikel Ilmiah. Jember : Universitas Jember.

\section{Regulations}

Kitab Undang-Undang Hukum Perdata

Undang-Undang Nomor 2 Tahun 2014 tentang Perubahan Atas Undang-Undang Nomor 30 Tahun 2004 tentang Jabatan Notaris.

Peraturan Menteri Hukum dan Hak Asasi Manusia Nomor 27 Tahun 2013 tentang Permohonan Izin Pelaksanaan Penjualan Harta Kekayaan yang Pemiliknya Dinyatakan Tidak Hadir dan Harta Peninggalan yang Tidak Terurus yang Berada Dalam Pengurusan dan Pengawasan Balai Harta Peninggalan (Permenkumham No. 27/2013).

Peraturan Menteri Hukum dan Hak Asasi Manusia Nomor 60 Tahun 2016 tentang Tata Cara Pelaporan Wasiat dan Permohonan Penerbitan Surat Keterangan Wasiat Elektronik (Permenkumham No. 60/2016).

Internet

Anugrahni, A. 2013. Understanding Legal Certainty in https://ngobrolin Hukum.wordpress.com/2013/02/05/memahamikepastian-dalam-law/ (accessed November 18, 2020). 
Hariyanti, Eko et al. 2015. Cancellation of Deed of Will Grant Made before a Notary and its Legal Consequences at http://jurnal. Hukum.uns.ac.id/index.php/repertorium/article/view/654/612 (accessed November 11, 2020).

Jakarta, DKI Heritage Hall. 2020. Requirements for Registration of Wills inhttps://bhpjakarta.kemenkumham.go.id/index.php/jasa-publik/pengurusan-wasiat\#percepatan (accessed November 10, 2020).

Kurnia SH, Abi Jam'an. 2019. Duties and Functions of the Heritage Office.https://www. Hukumonline.com/klinik/detail/review/task-dan-function-balai-harta-peninggalan (accessed January 20, 2021).

News, Gres. 2017. Know the Principle of Legal Assurance. https:/gresnews.com/ news/tips/115702-menenalasas-kepastian-law/ (accessed November 18, 2020).

Surabaya, Heritage Center. 2020. Flow of Will Registration Services at https://bhpsurabaya.com/index.php/jasapublik/pengurusan-wasiat\#alur-pelayan (accessed November 10, 2020). 